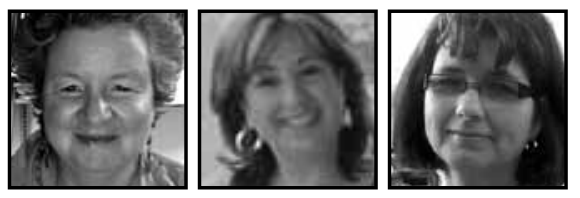

\title{
Re-forming Networks Through “Looping": An Ecological Approach to a Teacher's Incorporation of New Technologies in Early Childhood
}

\author{
Teresa Strong-Wilson and Sheryl Smith-Gilman, McGill University \\ Penny Albrant Bonneville
}

\section{ABSTRACT}

In this article, we discuss a teacher's agency and digital pedagogy who, following a four-year Learning with Laptops professional development initiative, relocated from a Grade Six to a Grade One class. An ecological perspective on teacher agency combined with Actor Network Theory underscores the "repertoires for manoeuvre" available to teachers (Priestley et al., 2012, p. 211). The early childhood classroom presented unique openings for "looping" elements of the teacher's previous network into a new context. Through re-forming networks, new spaces for digital pedagogy materialized.

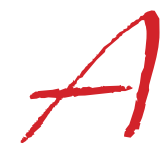

dults often scramble to keep up to date with the multitude of technological devices while at a very young age, children often actively seek out the plethora of toys and tablets embedded with computer chips that sing, talk, and dance at the press of a button or the swipe of a finger. Ipad and cellphone apps (applications) intended for young children now number in the thousands (Szabo, 2011). As the contemporary generation of children settles into the first years of school, teachers are discovering that young learners growing up with technology process material differently from previous generations (Oblinger \& Oblinger, 2005; Zevenbergen \& Logan, 2008). Teachers have often been resistant to incorporating new technologies in the classroom, especially with young children (K-3) who have been considered as too young or not yet developmentally ready, too impressionable, 
or better served by outdoor play (Linebarger \& Piotrowski, 2009; Plowman, McPake, \& Stephen, 2010). Professional development in the area of new technologies has largely focused on older students (aged 8 and up). Our article focuses on the "looping" that one early childhood teacher used to spark technology integration within the primary wing of her school by connecting older with younger students. Our article could have also been called "upstairs/downstairs." Early childhood teachers often live "downstairs" in schools while upper elementary classes occupy the upper floors. While this arrangement is often for very practical reasons and does not imply a hierarchy, it can also remind us of how young children-and ECE teachers - are often underestimated or misjudged (Kane \& Mallon, 2006). Penny presently lives "downstairs." She began her career teaching early childhood then experienced a turn in her practice when, as a Grade 5/6 teacher, she moved "upstairs" and became part of a professional development initiative called "Learning with Laptops" (LWL). Inspired by her new-found vision of teaching grounded in new technologies, Penny returned "downstairs" to the primary wing. One of Penny's larger goals, which also became part of the school mandate, was to promote technology integration in the primary wing. In this article, we see how Penny struggled to manoeuvre her new-found sense of agency in the primary wing. We suggest that to understand how she "looped" (moved forward) elements of her previous network into her new context, we need to take an "ecological" perspective on teacher agency.

\section{New Technologies and Early Literacy}

While early literacy intervention has been the by-word of early childhood research and practice for at least the past three decades, only recently has research and practice attended to early digital literacy (Flewitt, 2011). Most studies have focused on technology use of children ages 8 and up (Ito et al., 2009). Lankshear and Knobel (2003) surveyed the contents of nine major journals between 1999 and 2002, searching for literacy and new technology studies of children up to 8 years old; most articles focused on technology as a support to print literacy. Building on the Lankshear and Knobel review, Burnett (2010) reviewed studies involving young children that were published between 2003 and 2009. Across the 36 articles selected from the 698 reviewed, Burnett identified three trends: technology was used to deliver literacy, or technology was a site for interacting with others around texts, or technology supported meaning-making. The majority of articles (23) continued to fall into the first category, in which the focus was on print literacy (i.e., phonological awareness, reading comprehension, vocabulary). Four studies fell into the second 
category, where the focus was on children's talk. Nine studies explored technology as a medium for meaning-making, in which literacy was understood more broadly.

Debates around the place of technology in early childhood learning have also given rise to discussion about the teacher's role (McManis \& Gunnewig, 2012). The latest Position Statement of the NAEYC and Fred Rogers Center (2012) is that "the adult's role is critical in making certain that thoughtful planning, careful implementation, reflection and evaluation all guide decision making about how to introduce and integrate any form of technology or media into the classroom experience" (McManis \& Gunnewig, 2012, p. 6). However, the research upon which the present article is based suggests that more is involved than a teacher's thoughtful planning. Technological innovation can be an aspect of change at the classroom level, but it also implies a broader shift, which involves not just a teacher but a network: teachers, administrators, students, and potentially the broader community, local and global. It also involves the "non-human" network of infrastructure, which needs to be in place in order for teachers to be able to access and use technology in their pedagogy. Penny faced two main challenges: a) the adaptation of her pedagogical knowledge around new technologies to working with young children, and b) the creation of a "culture" of digital pedagogy in the primary wing of her school. The first challenge she readily achieved. The second one proved more challenging. We propose a theoretical framework of the ecology of teacher agency combined with actor-network theory to understand Penny's classroom achievements in the primary wing. She used her "network" of her past Grade 6 students to "loop" change forward. Penny's story helps us to better understand how incorporating new technologies within schools is not just about teachers but about the networks teachers navigate to help accomplish change.

\section{Teacher Agency and Educational Change}

New technologies present one of the greatest challenges to schools, on multiple levels. They require decisions about the allocation of resources. Probing questions may be raised by parents or school board members about the difference that new technologies actually make to student learning. Teachers are aware of how "plugged in" students are outside of school and struggle to make the curriculum interesting and relevant. The so-called "teacher factor" with respect to incorporation of new technologies in schools is often framed as a problem of how to generate teacher agency (UNESCO, 2008). Agency has been considered as an essential 
component of teacher change and curriculum reform (Hibbert, Heydon, \& Rich, 2008). Traditionally, agency has been understood as the capacity to respond constructively to change by acting autonomously, despite external constraints (Priestley, Edwards, Priestley \& Miller, 2012). Agency tends to be associated with such words as: "selfhood, motivation, will, purposiveness, intentionality, choice, initiative, freedom, and creativity" (Emirbayer \& Mische, 1998, p. 962). In recent years, other ways of understanding agency have been explored (Priestley et al., 2012), including collective agency, contextual approaches to agency, agency of networks (Fenwick \& Edwards, 2010), and ecological notions of agency (Biesta \& Tedder, 2007).

Sociologists Emirbayer and Mische (1998) think of human action as social engagement. This involvement with others is informed by the past (e.g., habits), by the future (the capacity to imagine alternatives), and by the present (the ability to mobilize past and/or future to address present situations). Emirbayer and Mische refer to each of these as, respectively, iterative, projective, and practical evaluative forms of engagement. These are useful ways to think about agency as not ONE thing but as multiple, depending on the context in which we find ourselves. The possibilities for human agency change over the life course, depending on where we are, at what time in our lives, in relation to which other people. By seeing agency as contextual, we can understand how teachers manoeuvre agency within any given situation (Priestley et al., 2012).

One direction in which this contextual concept of agency has been developed in adult learning is ecological: "by means of an environment rather than simply in an environment" (Biesta \& Tedder, 2007, p. 137). In other words, individuals interact with one another and with their environments but those environments also influence (enable and constrain) teachers' agency. When speaking about technology integration within larger institutions like schools, the environment also includes technological infrastructure (viz., machines, places to store them and means to access them) and resources (those who are knowledgeable about technology). Actor-network theory (ANT) is interested in the formation and sustaining of networks, including the relationships between human and non-human elements: their interconnections as well as the struggles and negotiations for power, which can involve: creating roles, setting policies or routines, and applying for funding (Fenwick, 2012). While ANT has largely been applied to large, powerful networks, it has also been used as a lens to understand how knowledge and practices move within schools especially during times of educational reform, and teacher professional development (Riveros \& Viczko, 2012). 
A contextual theory helps us understand the teacher as social actor in relation to other social actors. Actor-network theory helps us understand how the formidable presence of technology influences educational reform, which affects the ecology of teacher agency. What Fenwick (2012) calls an "ANTish" approach to ANT can help locate the points at which teacher agency is interrupted and derailed, as well as identify what helps mobilize teacher creativity and innovation, thus contributing to a more nuanced understanding of the project of introducing technology in schools across grades (e.g., in a primary wing).

\section{The Post-LWL Context}

"What happens to student and teacher engagement when the tools are withdrawn or diminished?" (Strong-Wilson, Harju, Mongrain, \& Thomas, 2008, p. 10). This was one of the main questions motivating the Balancing Literacies project, which emerged in the post-LWL landscape following a research collaboration between McGill University and New Frontiers School Board that had transitioned through four successive two-year teacher cohorts, involving 28 teachers in all. Learning with Laptops (LWL), a New Frontiers initiative, had used a teacher action-research approach to gather and share data in collaboration with a research partner, McGill University (in a research project called Changing Literacies, Changing Formations). Key tenets of the co-created professional development model were face-to-face meetings, a teacher blog, documentation of practice, and public sharing of research (Strong-Wilson et al., 2012). The school board provided infrastructure: class sets of laptops, with some "topping up" and refurbishing of computers by administrators of the participating schools. Central was the provision of ongoing technical and pedagogical support from the LWL leader, Bob Thomas. The PD initiative marked a turning point in teachers' lives (Strong-Wilson et al., 2012). One of the LWL reports prepared for the school board concluded with the question of what would happen when the tools were withdrawn: the hardware, support, and collegial collaboration. What would happen when those elements became detached from their LWL ecology, in which teachers felt energetic and supported, and became translated into the school context, in which LWL teachers would likely be positioned as agents of school change? This was the main question motivating the post-LWL Balancing Literacies research.

While LWL attempted to ease the transition, for instance by having principals participate in LWL and develop re-investment plans as the focus of their research, the shift back to the school context was nevertheless abrupt. Penny Bonneville, who is a co-author on this article, was one of those LWL teachers. 
The Balancing Literacies project ${ }^{1}$ on which this article is based used a qualitative research approach to study the phenomenon of teachers' negotiating literacies and the meanings that social actors ascribe to events and experiences (Denzin \& Lincoln, 2003; Stake, 1995); the research invited teachers to develop their own questions, as part of an action research design, similar to the one used in the LWL research. For the LWL "teacher graduate," the post-LWL landscape involved a negotiation of literacies, with LWL teachers being positioned as leaders in school reform. Over 2010 and 2011, classroom observation and interviews took place with five elementary classroom teachers. One LWL teacher, who is the focus of this essay as well as one of its co-authors, had recently moved back to teaching early primary education, and was charged with leading the integration of technology within the primary wing of her school. Sheryl and Teresa met with Penny to see what she was interested in investigating. Sheryl became the primary contact, visiting seven times (totaling 22 hours) with 68 minutes of videotaped classroom interactions.

In the first year of Penny's return to the primary wing, early childhood teachers at her school were not yet ready to engage with the technology, for reasons of inexperience, caution, and feeling overwhelmed at the thought of having to integrate yet another teaching tool into their daily routines. Although Penny was there to offer support, the thought of yet another "job" to do was unappealing to many. "I was very fortunate to have been given formal training and an incredible support system for two years before exploring technology on my own. These teachers were asked to do the same without the training" (Penny, Personal Communication, April 20, 2013). Penny therefore looked for other means to "manoeuvre" teacher agency with respect to new technologies within her classroom and eventually, the primary wing. Penny initiated a research wiki, in which she collected and posted information as well as reflective thoughts on what became her mentorship project. In this article, Penny tells the story of her project, drawing on the wiki as primary material.

\section{Penny's Context}

School board priorities were on reading and writing, supported by technology, but with the emphasis moving towards print and the engaging of children with books. The Daily 5 program was exemplary of this focus, and was mandated in all elementary classrooms across the board. ${ }^{2}$ One example of how technology could support literacy was evident through school subscriptions to Tumblebooks, a website where children could click on the pages and hear a story being read to them; 
Penny was instrumental in this change, as her principal proudly pointed out (Interview with principal, Dec. 13, 2010). At Penny's school, equipment was also a priority: providing each of the two floors with a mobile lab. A lab had already been put into place "upstairs," while the "downstairs" primary grades section was outfitted with 10 iBooks, 5 iPads, and 5 iPod touches. Penny was made responsible for downloading the apps (applications), which largely focused on reading and math. When asked how technology supported the Daily 5, the principal identified the Smartboard as key. Just about every class had one, she maintained, a tool which allowed for greater interactivity and was more suited to children's contemporary learning styles: "being able to touch the screen and have it move or attached to a link on the internet, to me, it's all part of [it]: it's the reading, the writing, the media, it's the understanding; it's all there" (Interview, Dec. 13, 2010). The principal acknowledged some of the post LWL "network" challenges: some teachers struggled with integration, the availability and upgrading of equipment remained an issue within diminishing technology-targeted funds, including the elimination of funds to mentor others. Supportive of Penny, the principal acknowledged the importance of the tools: "If the teacher doesn't have the tools, then they don't have a way to learn it." The principal also reinforced the importance of the Daily Five, to which she believed technology would lend its support to build students' literacy "stamina" (Interview, Dec. 13, 2010).

While moving "downstairs" to the primary grades was an enormous change for Penny, she was committed to her practice of integrating technology. Penny was aware that technology implementation was minimal in the early grades of her school and focused on taking on a mentoring group of "expert" Grade Six students (former LWL students) to help her Grade One class use laptops by the end of the school year. Her research questions were: How can technology stimulate collaboration between older and younger students? How can this partnership support sustainability of managing technology effectively in our school?

\section{The Mentorship Project: Penny's Story}

\section{Living LWL Upstairs}

My journey began in 2006 when I joined an action research project involving my school board and McGill University. It was a two-year project during which I taught in a totally immersive technological environment. My primary role was being a teacherresearcher. I co-taught the same group of Grade 5/6 students with a French colleague, who was also in LWL. I was part of a network of other LWL teachers, with support from the 
board in the person of Bob Thomas and support for the research by the McGill team. It was a golden opportunity.

I searched for methods that would inspire and excite my learners. For example, poetry took on a new dimension, as when students searched the Internet for poets and different styles and examples of poetry. My colleagues reported that the schoolyard was buzzing, my students reciting limericks and tongue twisters! Another outstanding project was digital storytelling. Students created a visual concept of "Romeo and Juliet." Students created multi-media presentations that incorporated movie, voice, sound, and musical effects. Our music specialist eagerly became involved. Students witnessed the collaboration of two teachers with very different areas of expertise. The project flourished, becoming more complex by the second. It was Reform practice at its best. Students were inspired with an unexpected passion and appreciation for a historical piece of literature.

Moving Downstairs: Technology Integration with Grade Ones

In 2010, I was asked to move from Cycle Three to a bilingual Cycle One class, my mandate being to build technology-based learning situations with primary students. A mobile cart was purchased for the ground floor early grades, with ten MacBooks, five iPads and five iPod Touches. Teacher training sessions were organized. The network was ready and functional by January.

January

For 3 weeks now, Ipads have been integrated into my Daily Five Program. During the first week, every child easily explored the iPad / iPod Touch devices. A variety of apps (Math, Sight Word/Vocabulary building, and basic French vocabulary) were preloaded. Within three weeks, students were autonomous in their learning.

When entering uncharted waters, simple safe rules need to be established. Details were critical: labeling and color-coding earplugs to avoid confusion and for proper hygiene, and forming groups for fair Daily Five rotation. Ultimately, my goal was to have students using MacBooks and exploring bookmarked sights within our School Board Portal by June.

However, Internet access meant obtaining parental permission, which I didn't have yet. Permission slips needed to be returned before we could continue. I needed to show the children how to use their codes (username and passwords) and log into the portal. Overwhelmed, I sought help from my former students in Cycle Three experts: former LWL students. 


\section{Tapping Into My Network}

March 29

I posted a mentors "sign up" sheet for grade six students. By the end of the first day, one student responded, leaving me surprised and disappointed. Nevertheless with some encouragement, by Thursday afternoon, I accumulated 12 names. The very first student to volunteer was a boy new to our school who was having a hard time adapting. He asked me daily, "When are we going to start?" A week went by. Sixteen students signed up.

April 8

My excited student volunteers would meet Friday noon in my classroom. The secretary repeated our message in our Morning Announcements over the intercom. The students arrived promptly. However my list of sixteen had dwindled to six.

I explained the two stages of the project. Stage one: training my mentors to support grade one students to access an Internet browser, find the portal, log in using their username and password and then log into their electronic portfolio. Once in ePearl, mentors would show the younger students how to upload photos and videos. They would help them write a reflection on the uploaded artifacts. Lastly, mentors would show students how to make a voice recording of themselves reading. Stage two was to access and explore Abracadabra.

The mentors were excited to start. Unfortunately, two sessions would have to be held since the group was divided into two homerooms. Challenges with finding a convenient day (i.e., amid Ped days, holidays) led us to meeting on April 13 at 12:30. "Bad luck 13" came into play. All of my mentors but one had double booked themselves or were absent. When you get kicked off the horse, you need to climb back on! My new strategy was to speak with colleagues and arrange a mentor training day. I wanted them to be confident and knowledgeable when it came time to interact with the younger students.

April 27

I initiated another lunchtime meeting with my mentors. The secretary, through daily announcements, reminded students. The lunch bell rang and I waited with bated breath. My group of four mentors was now reduced to two. Never losing faith, I was thankful to have two dedicated students. We were ready to proceed. 
The older students would demonstrate beginning procedures, which my students would repeat independently. I created a checklist that began with, "How do you turn on the computer?" Subsequent headings followed: "Entering a book title in ePearl" and "Taking a voice recording sample." Final steps included "saving your work," logging out of the portal, and shutting down.

My two mentors came after lunch, greeted by highly receptive grade one students. The mentors confidently talked the younger ones through the whole process. During recording time, the mentors discovered that the classroom was too noisy. They took the initiative and asked if they could move into the hallway. I was glad they took ownership of the situation. They were kind and patient with the younger students. When they were in the hallway, I followed and videotaped. A problem had occurred during the recording portion. Students could not be heard when they played back the recording. Both mentors problem-solved and agreed that next session, they would need headphones with a microphone to record properly. Towards the end of the session, the mentors transferred the computer to the youngsters and gave them hands-on time. Thirty minutes passed quickly. The mentors put away all the material and left with big smiles on their faces. When I asked if they wanted to come back, their answer was a big YES!!

Friday May 6

My mentors are keen, dependable citizens. My proudest moments were watching them set up the equipment and address important details. They were instant problem-solvers and pillars of patience with their mentees. I take pride in knowing that I taught these students last year in grade five. I am proud and thankful to have them in my classroom.

When asked why he was mentoring, one mentor simply replied: "Because I get to use the laptops!" When someone asked me why I became involved with the LWL project, I answered the same, "Because I get to use laptops!"

May 17

My loyal mentors, my partners, have come officially for about one month. I've become observer rather than instructor. I began integrating laptops into daily instruction. I preloaded the laptops with a "Note Book File" called The Life Cycle of Living Things. In the morning I showed the lesson on the Smart Board so students could see the links. After recess, I set up eight students and let them go! The children learned to navigate, moving from one web page to another by opening and closing different screens. They were able 
to reload "Note Book" if they accidentally closed the window. They independently listened to songs, watched video clips, played games, and visited websites. It was great. A large "thank you" goes to my mentors!

\section{Looping}

June

I have been familiarizing my students with laptops. They're getting quite good and are diligent at asking questions if unsure. Good practices and a solid foundation have been established. The mentors have been unable to come for the last week due to exams and fieldtrips. However next week, they will be modeling their mentorship to two grade five students, so that the process can continue next year. I have chosen two students. All parties involved are keen and prepared.

\section{September}

My year began with the golden opportunity of remaining with my Grade 1 students, who are now in Grade 2. Looping (moving up with my class to the next grade) entered my vocabulary; it is a word I have grown to cherish, in more ways than one. It was also a practice I was applying to the mentors.

My new grade six mentor reminded students how to log in and enter the school board portal. Although appearing simple, it entails several tedious steps. Under the mentors' guidance, students navigated to our classroom community, allowing me to integrate technology into the "Daily Five" practice.

My students were ready to move onto bigger, more impressive projects, and so was I. An extended project began: an Anti-bullying campaign wherein the Grade Two students paired with Grade Six students to learn the steps involved in creating an iMovie. Several technological tools were incorporated such as a digital storyboard graphic organizer and cameras for photography. The young children acquired skills in transferring formats to QuickTime, transcribing their stories, formatting frames, loading, inserting and cropping their pictures, adjusting time durations and inserting transitions. Students labored for 7 hours on their individual movies, each of which had a duration of one and half minutes!

What fascinated me was that all students enjoyed complete autonomy with the technological tools. They took control of their learning. They collaborated and made creative choices. Students' work was showcased when we invited the school to view the movie productions. An Open House welcomed families and community members to celebrate our students' success. I am so proud of them all: the mentors and my students! 


\section{Discussion}

Penny's story tells how a teacher began the integration of new technologies with a notion of agency carried over from her participation in a highly supportive professional development context. Penny called LWL a "golden opportunity," like Charlie's ticket in Roald Dahl's famous Charlie and the Chocolate Factory. Post-LWL, Penny and her LWL Grade 6 colleague were successful in establishing a new network with non-LWL teachers "upstairs" when they secured a professional development grant, which allowed for release time. Penny's collaboration with the Music teacher also continued. In the post-LWL world, teachers had to increasingly negotiate their own agency in their own school context. Once Penny moved "downstairs," she had to think about how she could use her existing networks and build new ones. The primary teachers had to be brought on board slowly. Some social actors were positioned to be more supportive than others. The principal, for instance, played a key role in encouraging Penny's integration of new technologies in the primary wing by positioning her as a mentor of other teachers and more importantly, by providing the non-human tools, the mobile lab. She also allowed her to "loop" upward with her Grade 1 students into teaching Grade 2. The tools represented new learning opportunities for Penny, which stimulated her own desire to find creative ways to incorporate iPads and iPods in the primary grades.

Penny's creation of a mentorship project with her former Grade 6 LWL students represented a shift in teacher agency from being localized in the teacher as leader and capacity builder, to agency as more distributed: "manoeuvred" among a wider network of social actors: the student mentors, Penny's own Grade 1 students (who "looped" with her), the principal (who had the foresight to allow for the looping), Penny's "upstairs" colleagues, and the Grade 5/6 teachers with whom she later paired on a bullying project. Through this manoeuvring, Penny was able (with her student mentors) to bring her primary students from learning how to log in to creating an iMovie: a project that more closely resembled the exciting digital pedagogy that Penny had been part of in her culminating year in the LWL project.

From the perspective of early digital literacy, Penny also negotiated the several pressures on the use of technology in the primary classroom. While the "apps" primarily served the school and Board mandate of reading, in which technology is positioned as "deliverer of literacy," the extended network with the Grade 6 students and teachers, through the bullying project, allowed for technology to become more of a "medium for meaning-making" (Burnett, 2010, p. 254). 


\section{Conclusion}

Penny's mandate in moving "downstairs" to Grade 1 was "to introduce technology ... from the bottom up" (Interview, Jan. 25, 2011). This particular mandate initially proved challenging. An ecological understanding of teacher agency draws attention to the "repertoires for manoeuvre" available to a teacher at a particular point in time in particular circumstances (Priestley et al., 2012, p. 211). Penny had to seek out or create other networks, radiating outwards from the environment that was most within her control: her own classroom. An Actor Network Theory approach to educational change emphasizes the interaction of human and non-human tools. Penny's desire to keep her LWL professional development knowledge moving and active in her pedagogy would not have been possible without "the little network that is happening at all the [learning] stations" in her classroom "especially [with] the technology" (Interview, Jan. 25, 2011). Children were exploring apps on iPads and iPod Touches. This network was made possible by the tools, which were made available through the principal manoeuvring school funds. What Fenwick (2012) has usefully postulated as an ANT-ish approach to educational change, allows us to appreciate how different forms of network-like spaces can be created; spaces that may be in flux and provisional yet constitute the primary, ecological sites for agency. An ANTish approach, for instance, points to the importance for Penny of maintaining her "upstairs" network, even though she was no longer a Grade 6 teacher. It was from this network that future student mentors for the primary wing would be drawn: "The trend would be, if I am looping to get that base and send them [the students] off, by the time the teacher gets them in grade three, and if the teacher is willing to incorporate technology into their pedagogy ..." (Penny Interview, May 26, 2011). Through re-forming networks, new spaces for digital pedagogy with younger students may materialize. This flexible space continued to move over the following year, with the primary wing now slowly coming on board.

\section{Upstairs/Downstairs}

As time moved on and projects became more visible to the school and possibilities of integration were being discussed, teachers' interest piqued. The turning point happened after our "Open House" and my students' work had been showcased for the entire school to see, which ignited a spark among my fellow teachers. By the end of my second year downstairs, there were two primary teachers who had come on board and were using the technology cart. The school purchased another ten iPads, which brought our total to fifteen. I was still the "go to girl" but my role intensified downstairs. I created an 
agenda system where teachers would reserve times within our daily schedule to secure the cart. We are now in year three of integrating technology in Cycle One. Our third year began when four of my colleagues and myself applied for our P.I.C (Professional Improvement Committee) funds and took a trip to Boston to attend the "iPad Summit." The trip was amazing and set the tone for the rest of our school year. The cart is now in use all day long, five days a week, by teachers in the primary wing. The Daily Five program has initiated the greatest participation of teachers in integrating technology into their pedagogy. Teachers will ask me to find certain apps that complement their unit of study and I load them on the iPads. I have written another PDIG proposal to strengthen this area of integration for next year. We are still at the beginning stages when it comes to sharing best practices but are definitely headed in the right direction. The fire is burning bright at our school.

\section{Notes}

1. This research would not have been possible without the support of McGill's Internal Grants (SSHRC) program, for whose financial support we are grateful.

2. The Daily 5 (created by Jane Boushey \& Dale Moser) is a series of literacy tasks arranged at different learning centers in the classroom. In groups, students rotate around the centers throughout the week. Typical centers may include: 1. Read to self; 2 . Read to someone; 3 . Listen to reading; 4 . Work on writing; 5. Work on words. The objective is to support students in developing literacy skills according to their abilities with their peers.

\section{References}

Biesta, G., \& Tedder, M. (2007). Agency and learning in the lifecourse: Towards an ecological perspective. Studies in the Education of Adults, 39(2), 132-149..

Burnett, C. (2010). Technology and literacy in early childhood education settings: A review of research. Journal of Early Childhood Literacy, 10(20), 247-270. doi: 10.1177/1468798410372154

Dahl, R. (1964). Charlie and the chocolate factory. New York: Puffin Books.
Denzin, N. K., \& Y. S. Lincoln (2003). Strategies of qualitative inquiry. Thousand Oaks, CA: Sage.

Emirbayer, M., \& Mische, A. (1998). What is agency? American Journal of Sociology, 103(4), 962-1023.

Fenwick, T. (2012). Reading educational reform with actor-network theory: Fluid spaces, otherings, and ambivalences. In T. Fenwick and R. Edwards (Eds), Researching education through actor-network 
theory. Philosophy Education Society of Australasia.

Fenwick, T., \& Edwards, R. (2010). Actor network theory and education. London: Routledge.

Flewitt, R.S. (2011). Bringing ethnography to a multimodal investigation of early literacy in a digital age. Qualitative Research, 11(3), 293-310.

Hibbert, K. M., Heydon, R. M., \& Rich, S. J. (2008). Beacons of light, rays, or sun catchers? A case study of the positioning of literacy teachers and their knowledge in neoliberal times. Teaching and Teacher Education, 24, 303-315.

Ito, M., Baumer, S., Bittanti, M., Boyd, D., Cody, R., Herr, B. et al. (2009). Hanging out, messing around, geeking out: Living and learning with new media. Cambridge: MIT Press.

Kane, R.G., \& Mallon, M. (2006). Perceptions of Teachers and Teaching. A research report to the Ministry of Education and the New Zealand Teachers Council. (pp. 34-36). In R. Kane (Ed), Perceptions of Teachers and Teaching: A Focus on Early Childhood Education. Ministry of Education, New Zealand.

Lankshear, C., \& Knobel, M. (2003). New technologies in early childhood literacy research: A review of research. Journal of Early Childhood Literacy, 3(1), 59-82.

Linebarger, D.L., \& Pitrowski, J.T. (2009). TV as storyteller: How exposure to television narratives impacts at risk pre-schoolers story knowledge and narrative skills. British Journal of Developmental Psychology, 27(1), 47-68.

McManis, L.D., \& Gunnewig, S.B. (2012). Finding the education in educational technology with early learners. Young Children: Journal of the National Association of Young Children, 67(3), 14-25.

NAEYC \& Fred Rogers Center for Early Learning and Children's Media (2012).Technology and Interactive media as tools in early childhood programs serving children from birth though age 8 . Joint position statement. Washington, DC: NAEYC; Latrobe, PA: Fred Rogers Center for Early Learning at Saint Vincent College. Retrieved from [www.naeyc.org/files/naeyc/file/posi tions/PS_technology_WEB2.pdf].
Oblinger, D.G., \& Oblinger, J.L. (2005). Is it age of IT? First steps toward understanding the net generations. In D.G. Oblinger \& J.L. Oblinger (Eds), Educating the Net generation (pp. 2.1-2.20). Boulder, Co: EDUCAUSE.

Plowman, I., McPake, J., \& Stephen, C. (2010). The technologisation of childhood: Young children and technology in the home. Children and society, 24(1), 62-75.

Priestley, M., Edwards, R., Priestley, A., \& Miller, K. (2012). Teacher agency in curriculum making: Agents of change and spaces for manoeuvre. Curriculum Inquiry, 42(2), 191- 214.

Riveros, A., \& Viczko, M., (2012). Professional knowledge "from the field": Enacting professional learning in the contexts of practice. McGill Journal of Education, 47(1), 37-52.

Stake, R. E. (1995). The art of case study research. (pp. 50-68). Thousand Oaks, CA: Sage.

Strong-Wilson, T., Harju, M., Mongrain, N., \& Thomas, B. (2008). Report: Learning with laptops and changing literacies, changing formations. Retrieved from recit.csnewfrontiers.qc.ca/lwl/...files/CLCF_LWL_ Report_2008.pdf.

Strong-Wilson, T., Thomas, B., Cole, A. L, Rouse, D., Tsoulos, D. \& with teacher authors (Bonnie Mitchell, Kelly Ryan, Manuela Pasinato, Marie-Claude Tétrault, \& Penny Bonneville). (2012). Envisioning new technologies in teacher practice: Moving forward, circling back using a teacher action research approach. New York: Peter Lang.

Szabo, L. (2011). Smartest toys for kids can be the simplest. USA Today. Retrieved from http://usatoday30.usatoday.com/news/ health/wellness/story/2011-12-11/ Smartest-toys-for-kids-can-be-the-sim plest/51816042/1

UNESCO. (2008). ICT competency standards for teachers. Paris: UNESCO.

Zevenbergen, R., \& Logan, H. (2008). Computers used by preschools children: Rethinking practice as digital natives come to preschool. Australian Journal of Early Childhood, 33(1), 37-44. 


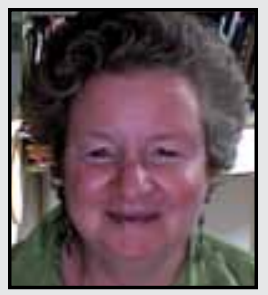

Teresa Strong-Wilson is Associate Professor in the Faculty of Education at McGill University. She is interested in changing literacies, memory, stories, social justice, Indigenous education, and teacher learning. She has published extensively in peer-reviewed journals. She has also authored Bringing Memory Forward: Storied Remembrance in Social Justice Education with Teachers (2008), co-authored Envisioning New Technologies in Teacher Practice (2012), and co-edited Memory and Pedagogy (2011). Forthcoming co-edited books include one on productive remembering and social action (Sense) and another on issues and alternatives with respect to the use of portfolios in teacher education (Peter Lang). She is also co-editor of the McGill Journal of Education.

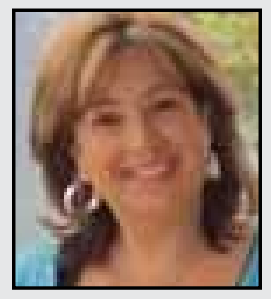

Sheryl Smith-Gilman has been involved in early childhood education for the past 30 years. She is a course instructor at McGill University and Concordia University in their Faculties of Education and at Vanier College in the Early Childhood Continuing Education Department. Along with presenting frequently at professional and academic conferences, Sheryl is the Reggio Emilia consultant for the Step by Step Child and Family Center in Kahnawake, Mohawk Territory and for the English Montreal School Board BASE daycare program. She is presently completing her doctoral research in the field of culture and learning in early childhood education.

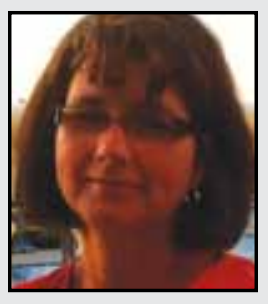

Penny Albrant Bonneville (B. Ed) has been teaching for 21 years. She is an early childhood specialist who has primarily instructed Cycle One and Cycle Three students in both English and French. Although she is an English Specialist, she has acquired many certificates in Cooperative Learning and Technology. She has presented at various conferences showcasing technology integration. Her passion for technology has led to numerous Professional Development seminars in Canada and the United States. 